1 脳の器貝的障㛃中、收も多いのは、感染後性であ るが、气の中で結核性蹃膜炎小全て生後 1 年泤队に発

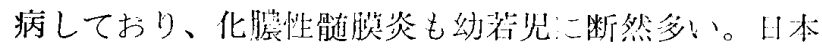

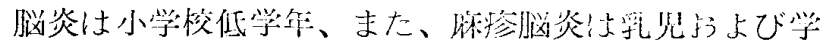
童剘に山がみられた。

2 知能障害の程度上発病年命との四係では 3 才以下 の発病势: I.Q.54以下のものが多く、6子以上の発 病者では、一般に一知能障寒が軽い。

3 病四と年令との则係は、もちろん、感染性は 3 才

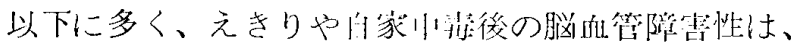

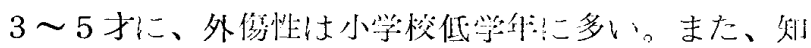

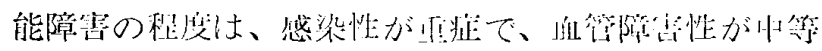
庭、外㑺性は伩も轻度である。

4 㾤等器作と知能障害の积废をみると、発作が出生 当時のみにあったものは、I，Q.が比較的に㡂く、出 生後より引つづきあるものでは、I.Q.54以下のもの が多数にみられる。

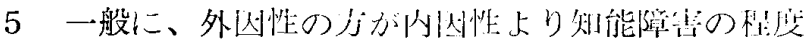
が高いと势われる。しかし、内因性の蒙古症と小故症 とで、I.Q.54以下が各々、76\%と65\%もあり、一概 にそうも霜えない。

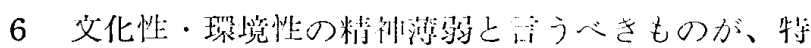
定の地域や家淤に份在与ることは碓かである。こし て、先れらは心理治将的な取报いと教行とによって如 能指数: 二著しい進少をみる。しかし、これも 3 才以前 に手をつけるJが、進少の度合の高いことを附就す る。

\section{6. 精神薄弱児の脳波分類について}

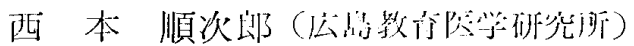

通常の学校教们にはついてゆけ始能打の子供を精到

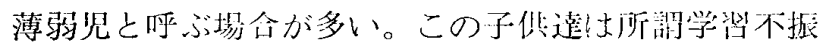

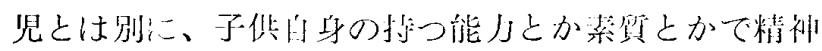

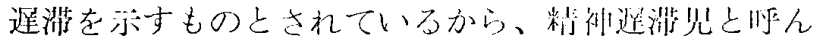
でもよい。

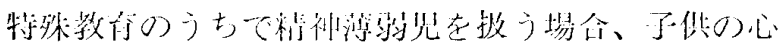

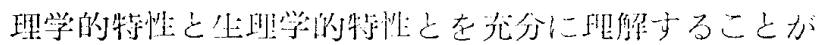

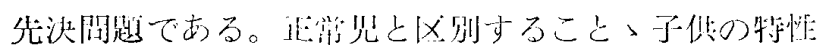

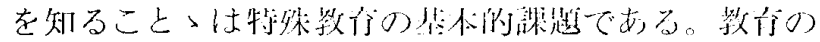

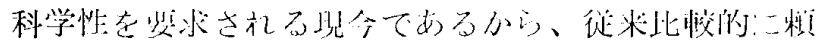

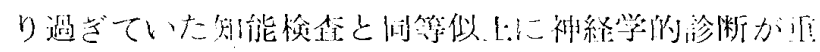

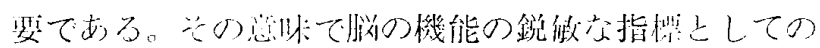

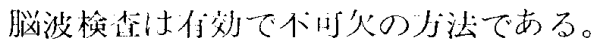

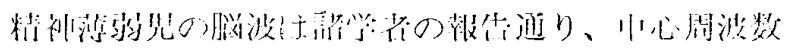

が10サイクル以下を示寸ものが多人、律斯が全般的：

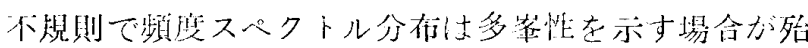

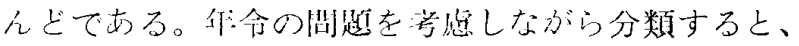
徐波及じ䢞波の多い尚振帷、低振幅のグループも市

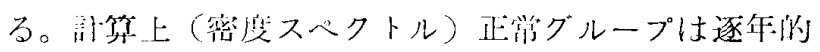

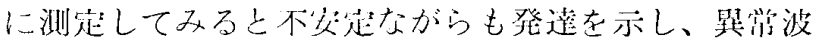

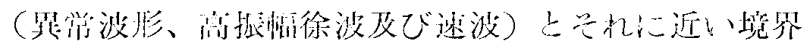

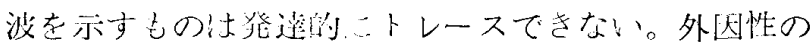

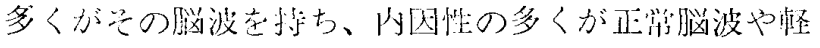

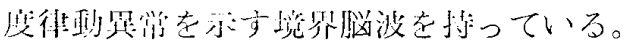

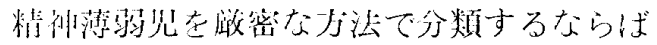

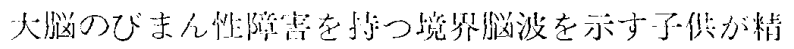

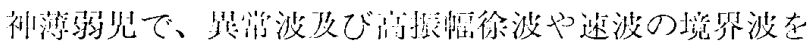

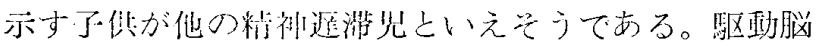

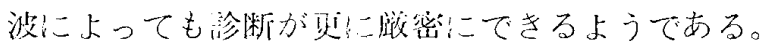

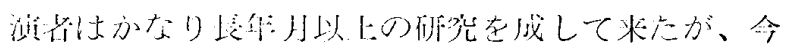
四ソ过及びヨーロッパ視然をしてみたり訋湔してみて 其近の梷を想めることができた。

\section{7. 特殊教育䂯究の根本問題}

$$
\text { 岩本㴓(岐大) }
$$

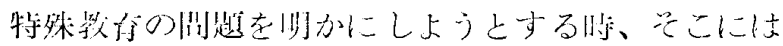
直ちに二つのノ们が现われてくる。一つは特殖大阔题

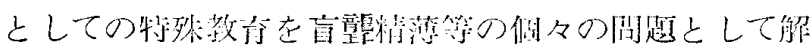

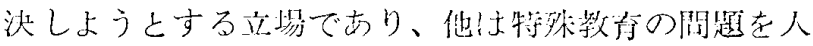

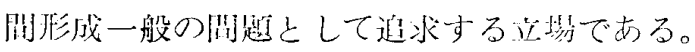

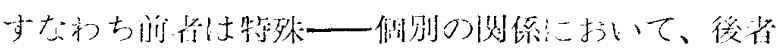

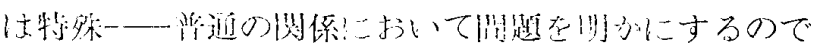

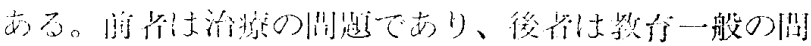
题である。

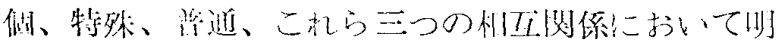

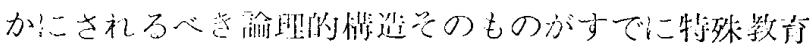
に㠺们心ものでは心くて、一般仙であることがまず光

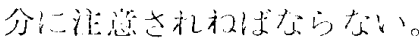

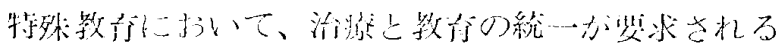

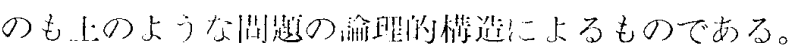

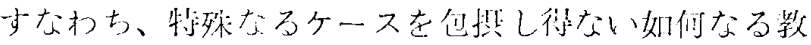

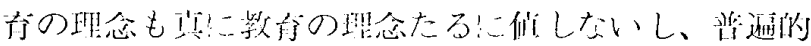

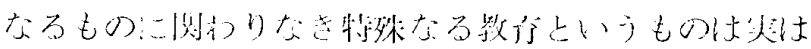

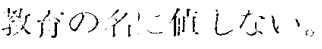

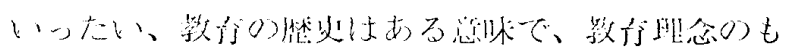

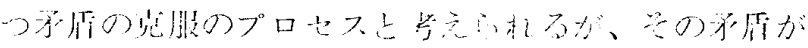

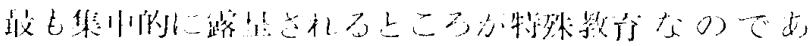
》。 


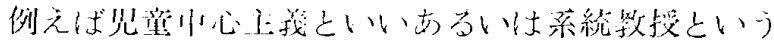

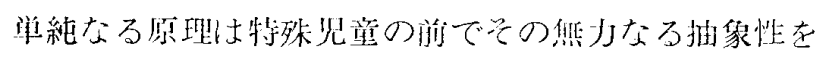

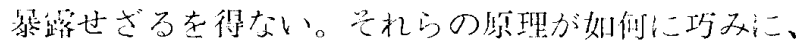

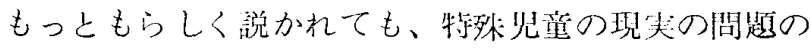

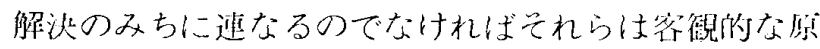

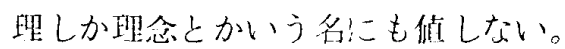

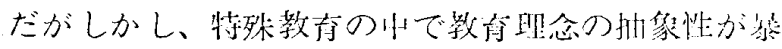

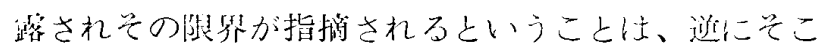

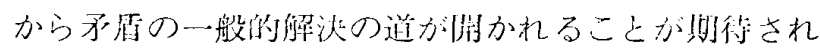
るということが大抽なのでる。

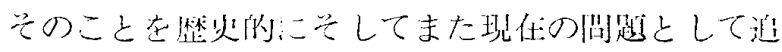
求してみたい。

\section{8. 精神薄弱者の社会適态に関する研究}

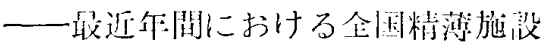

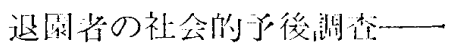

\section{○草 野 重 道

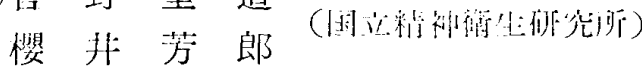

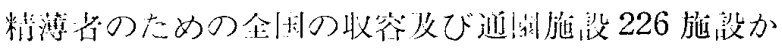

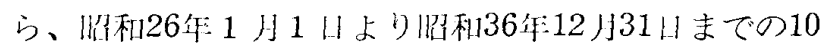

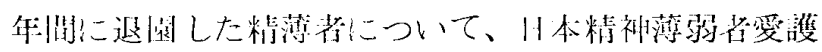

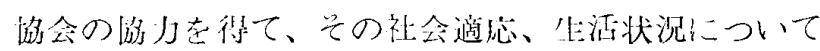

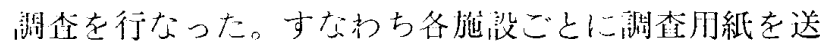

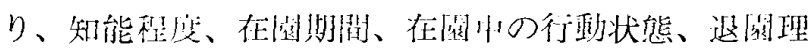

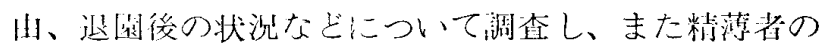

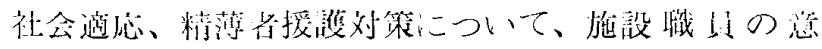
光、罗整などにつ、ても䯏查在行なった。

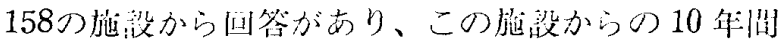

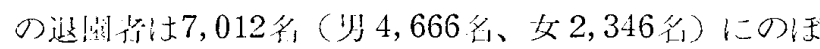

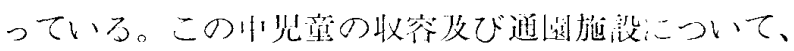
主汇進へててみる。

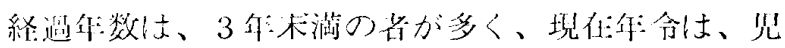

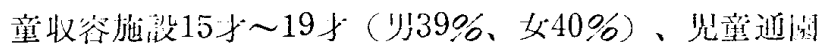

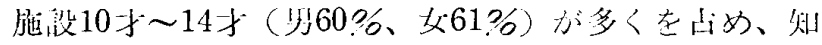

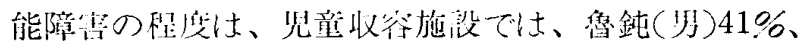

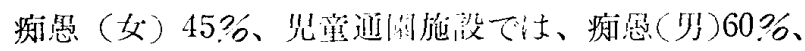

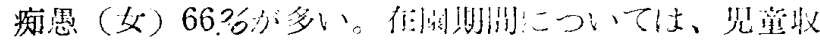

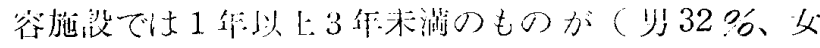

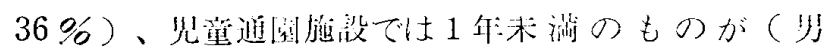

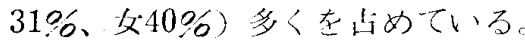

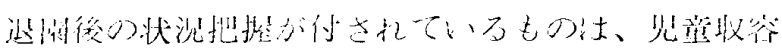

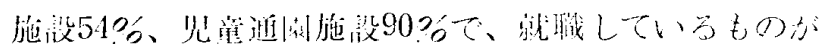

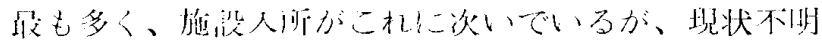

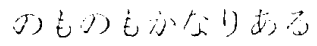

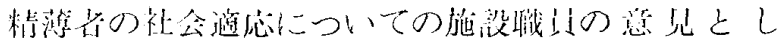
て、I.Q.50以上のもの、明朗、素㳀なもの、健症な もの、勒第整欲の古るもの、精视疾㭧のないもの、非 行のないもの、蒙族摩主の理解のあることなとこの条 件があげられている。また援濩站籍として、ことにア フターケアーの必装性が抬泟されている。

\section{9. 精薄児教育と貧困児教育との関係に関する 史的研究 (I)}

一一来宗市下谷万年传民学校に於ける 「低能贸」教序について二一

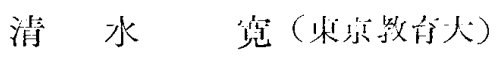

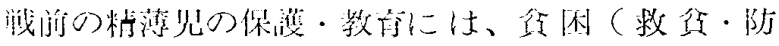
们）间题が非行间题（感化教有）と維合しながら、号

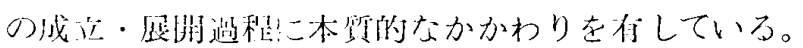

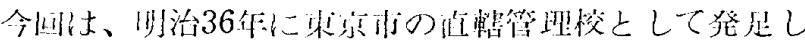

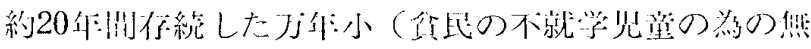

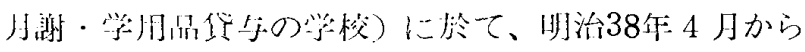
1 年浯だけ侙みられた「低能悓」の然の「特别学級!

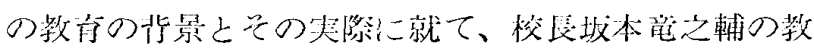
序の娊想と司践を中心検行した。

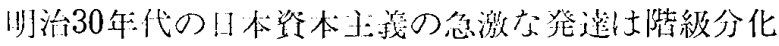
と大采の籍之化を一瓦深刻化したが、それに刘处寸心゙

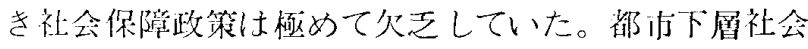
は犯罪や社会主䉝のプールとして次第に社会問題化 し、体制維持の为にも、細氏干弟の不就学を無くし天 皇例イデオロギーの浸透を叶らざるを得なくなってい

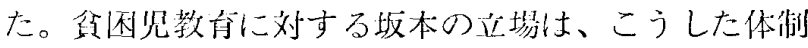

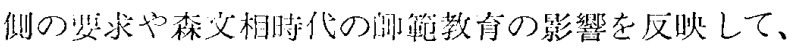

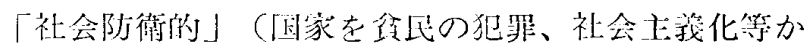

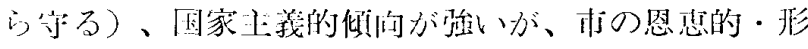

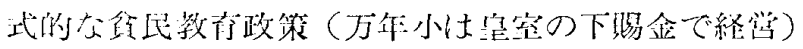

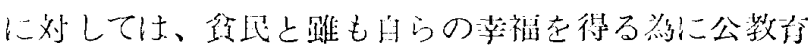

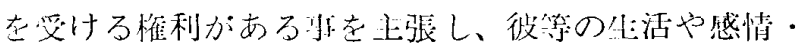

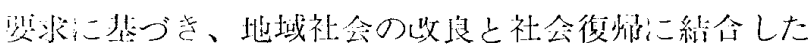

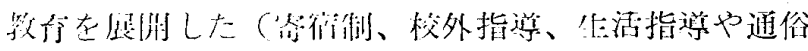

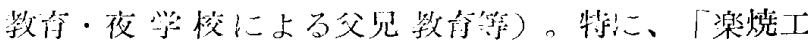

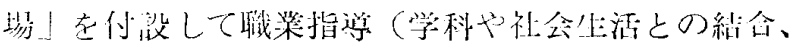

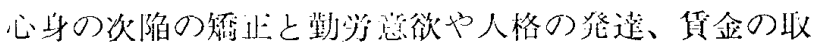

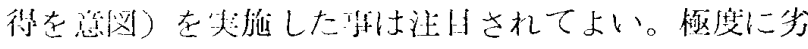

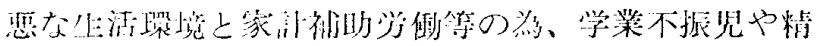

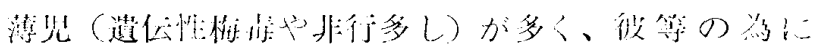

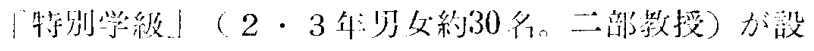

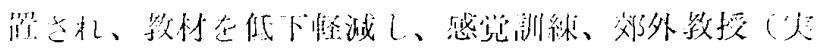

